\title{
MEDIJSKA KONSTRUKCIJA KOLEKTIVNIH SJEĆANJA: TRETMAN PROŠLOSTI U POLJU NOVINARSTVA, S OSVRTOM NA POSTDEJTONSKU BOSNU I HERCEGOVINU
}

\section{- Sažetak -}

U radu kritički sagledavamo prakse obrade događaja prošlosti u polju novinarstva, odnosno medije kao distinktivnu institucionalnu arenu suvremenih zajednica za uspostavljanje, održavanje i mijenjanje zajedničkih okvira razumijevanja i komemoriranja odabranih epizoda povijesti. Nastojimo ponuditi plauzibilna objašnjenja u pogledu odnosa između ,, kultura sjećanja,, $i$, ,kulture vijesti,.. Članak sugerira kako pristupiti nerijetko neshvaćenom području prošlosti u informativnoj djelatnosti, koja u svom djelokrugu, po definiciji, nema dimenziju povijesti nego socijalne situacije suvremenosti. Također, modeliramo ključne operacije i strategije operativne u oblikovanju repertoara novinarskih naracija prošlosti. Opisane prakse ispitujemo na primjeru postdejtonske BiH, analizirajući novinarski tretman konfliktnih žarišta nedavne ratne povijesti. Legitimiziranje etnonacionalnih vizija prošlosti posredstvom diskursa vijesti prepoznajemo kao dominantni rad u „,medijskom memorijskom polju,.. Ističemo dva ključna paradoksa takvih obrazaca obrade prošlosti: supostojanje međusobno oprečnih diskursa sjećanja i kodificiranja iskustava abjekcije istim skupovima signifikacija koji su i inducirali same ratne traume. Ukazujemo na najmanje dva uvjeta koja omogućavaju ove proturječnosti: neodređenost prošlosti, koncepcija vremena koju pretpostavlja postdejtonska BiH kao inherentno nedovršenal nesavršena država, i tehnologije kulturalizirianog upravljanja traumom, koje režimi „,terapeutske/tranzicione pravde,, upošljavaju kod ovladavanja uznemirujućom prošlošću u postkonfliktnim zajednicama.

1 Dr. sc. Mirza Mahmutović, Filozofski fakultet, Odsjek za žurnalistiku, Univerzitet u Tuzli, e-mail: mirza.mahmutović@untz.ba. 
Ključne riječi: polje novinarstva, diskurs vijesti, kulture sjećanja, traumatične memorije, postdejtonska BiH.

\section{Uvod}

Procesi proizvodnje, širenja i usvajanja znanja o povijesti i društvenointegrativnim figurama sjećanja neke zajednice, danas su neodvojivi od masovnih medija. Portreti prošlosti koje stvaraju i nude mediji u različitim žanrovima svoje produkcije - od fikcijskih, preko dokumentarističkih do faktografskih poruka - značajno uvjetuju naše percepcije ne samo prošlih nego i sadašnjih socijalnih situacija. Lični i kolektivni identiteti, također, nezamislivi su bez mnogobrojnih ,vještačkih memorija, pohranjenih u medijskim arhivama, koji nam omogućavaju da „doživimo,, prošle događaje, iako su se zbili mnogo prije vremenskog horizonta našeg života. Ipak, u dominantnim, paradigma medijske pismenosti, kao i andragoškim pedagogijama evidentno je odsustvo svijesti o ulozi medija u procesima simboličke konstrukcije prošlosti.

U ovom radu ukazujemo na značaj medija, posebno novinarske profesije, u oblikovanju javnog diskursa o prošlosti. Članak je organiziran u tri dijela. U uvodnom odjeljku sažeto prikazujemo ulogu medija u procesima oblikovanja kolektivnih memorija, te ukazujemo na važnost novinarstva, kao javnog foruma za odgovorno izražavanje različitih mišljenja, u kritičkom preispitivanju prošlosti. Također, sugeriramo kako pristupiti, nerijetko neshvaćenom, području prošlosti u informativnoj djelatnosti, koja u svom djelokrugu, po definiciji, nema dimenziju povijesti nego socijalne situacije suvremenosti. U drugom dijelu, zatim, razmatramo procese izgradnje „spirala signifikacije,, posredstvom kojih se tvore medijski diskursi sjećanja/ pamćenja, dakle, ključne operacije i strategije operacionalne u oblikovanju repertoara novinarskih naracija prošlosti. I, u konačnici, u trećoj sekciji rada prikazujemo ključna obilježja medijskog tretmana konfliktnih žarišta recentne ratne povijesti u postdejtonskoj $\mathrm{BiH}$.

Rad nastaje iz uvjerenja da bez poznavanja složenih praksi, operacija i strategija obrada prošlosti u polju medija, procesi medijskog opismenjavanja i cjeloživotnog obrazovanja ostaju uskraćeni za društveno značajan skup kritičkih znanja. Važnost razumijevanja medijskog tretmana prošlosti smatramo posebno važnim u postkonfliktnim zajednicama, poput postdejtonske $\mathrm{BiH}$, gdje je oblikovanje sjećanja na uznemirujuću prošlost bitan uvjet demokratske konsolidacije bh. društva i države. U tom smislu, stjecanje kompetencija za kritičku evaluaciju pojednostavljenih, mitoloških i 
ideoloških prikaza povijesti nerazlučivo je od obrazovanja samog građanskog etosa - sposobnosti za racionalno, argumentirano i odgovorno rezoniranje u prostorima javnosti.

\section{Aktuelna prošlost: kultura vijesti i kulture sjećanja}

U suvremenom društvu masovni mediji su neizostavno polje uspostavljanja, održavanja i mijenjanja zajedničkih okvira razumijevanja svijeta prošlosti. Oni su, zapravo, jedna od najefikasnijih institucionalnih arena za širenje i učvršćivanje onih diskursa sjećanja koji u nekoj društvenoj zajednici žele osigurati dominantan pogled na prošlost. S druge strane, mediji su također jedan od najpodesnijih javnih foruma za kritičko propitivanje dominantnih (elitnih) naracija prošlosti. Iako su „medijske reminiscencije,, u pravilu, pojednostavljene i dekontekstualizirane pripovijesti, koje, nerijetko, pogoduju i služe ideološkim (zlo)upotrebama povijesti, emancipativni potencijal medija u odnosu prema prošlosti - mogućnost da potaknu odgovornu, racionalnu i argumentiranu raspravu o ,kontroverznoj, prošlosti, problematiziraju produkciju mitologiziranih i popularnih historija, te promoviraju kritičke kulture sjećanja - nikada ne treba zanemariti.

Procesi oblikovanja kolektivnih memorija ${ }^{2}$ u modernom dobu neodvojivi su od medija, shvaćenih u najširem smislu kao skup svih materija, modaliteta i institucija posredstvom kojih se odvija komuniciranje.

Prije svega, masovni mediji „obnavljaju memorije,, (Hoskins, 2008). Tragove prošlosti, povijesne pojavnosti jedinstvene i neponovljive po svojoj naravi, mediji čine trajno pristupačnim, ponovljivim momentima. Čin skladištenja, naime, pretpostavlja operaciju perpetuiranja: mogućnost

2 Općenito kazano, kolektivna memorija odnosi se na klasu socijalnih pojava koje se tiču javne upotrebe prošlosti (Kuljić, 2006). Tri referencijalne jedinice - korpus znanja o/iz prošlosti, relativno uniformirana i distinktivna predstava prošlosti koju dijele članovi skupine te kulturno osmišljen odnos spram prošlosti (Dudai, 2002) - uzimamo za matrice kolektivne memorije. Organizirano društveno pamćenje, u tom smislu, ne iscrpljuje se u pukom skladištenju iskustva iz prošlosti. Njegova važnija funkcija je „strukturiranje rezultata aktivnosti opštenja, kojima grupa određuje osoben odnos prema sebi i svijetu,, (Kuljić, 2006: 8), i to ne samo (selektivnim) čuvanjem određenih sadržaja prošlosti nego i (organiziranim) zaboravom drugih. Studije memorija interesiraju se za društvene, političke, kulturne, ekonomske i tehnologijske činioce koji uvjetuju što, kako i zašto društvene skupine pamte i/ili zaboravljaju iz povijesti. U fokusu izučavanja su obrasci koji reguliraju procese društvene obrade znanja, vjerovanja i percepcija o prošlosti, planske i/ili spontane prakse čuvanja, prenošenja, nasljeđivanja, dorađivanja, izmišljanja, preinačavanja, potiskivanja i zaboravljanja sadržaja prošlosti. Za detaljnije o konceptu, genezi studija, teorijama, dimenzijama, opcijama, institucijama i zajednicama kolektivne memorije pogledati Kuljić (2006); Assmann (2008); Assmann (2011); Nora (2007); Connerton (1989); Misztal (2003); Wertsch (2004); Olick, Vinitzky-Seroussi \& Levy (2008). 
naknadnog reproduciranja, aktualiziranja sačuvanog sadržaja. U tom smislu možemo govoriti o medijima kao „produžecima memorija,,, tehnološkim surogatima za buduće publike u procesu spoznavanja prošlosti. Otuda je svaki medijski posredovan trag prošlosti u osnovi sadržaj namijenjen predanju, razmjeni, samoj komunikaciji. ${ }^{3}$ Historija masovnih medija to zorno svjedoči. Vidljivo je to kod pisma, koje je kao ,produžetak,, memoriji omogućilo neslućeno protezanje ljudskih iskaza u svrhu ponovnog primanja poruka, preko štamparstva, koje je omogućilo njihovo umnožavanje, sve do mobilnih elektroničko-digitalnih audiovizuelnih medija, koji su omogućili registriranje, pohranjivanje te ponavljanje i sasvim neočekivanih događaja. Mogućnost mehaničkog ponavljanja ad infinitum onoga što se egzistencijalno nikada ne može ponoviti, bitno je obilježje medijskog svjedočenja prošlih zbivanja.

Ipak, svaki proces obnavljanja neizbježno uključuje preobrazbe, zastarijevanja, izmještanja, diskreditiranja, u osnovi, nova o(be)smišljavanja autentičnih elemenata. „Amnezijski efekt,, neminovna je pojava u procesu obnavljanja memorija, bez koje je teško razumjeti, kako tvrdi Andrew Hoskins, načine pomoću kojih moderno društvo živi sa svojom prošlošću i mijenja je u sadašnjici (Hoskins, 2008: 155). U tom kontekstu, indikativni su uvidi o „kanibalizacijama memorija,, u globalnim tokovima vijesti (Zelizer, 2011): nizu procesa operativnih prilikom novinarske upotrebe arhivskog materijala, posredstvom kojih „lokalni mnemonički impulsi, bivaju uprošćeni, dopunjeni, izmješteni i preneseni u globalne kontekste, u konačnici, potpuno ili djelomično izmijenjeni. S popularizacijom i sveprisutnošću digitalno-mobilnih tehnologija ovi trendovi postaju još naglašeniji. Tako osim novinara, koji rutinski koriste mnogobrojne „blic memorije,, i prateće ,interpretativne obrasce,, s ciljem određivanja značenja aktuelnim događajima, u „memorijskim sklapanjima,, (Reading, 2011) u novomedijskom umreženom okruženju također sudjeluju i pojedinci-svjedoci zbivanja kao i razne heterogene skupine globalnog civilnog društva (mreže boraca za ljudska prava, udruženja socijalno marginaliziranih skupina, umjetničkih i znanstvenih aktivista itd.).

Sklopovi sjećanja, koji se obrazuju u ovom ,globitnom memorijskom polju, ${ }^{4}$ hibridni su konstrukti, sastavljeni podjednako kako od medijski

3 Ne iznenađuje stoga što i Jan Assmann, autor teorije o kulturnom pamćenju, ovaj fenomen sagledava $\mathrm{u}$ kontekstu ponovo primljene poruke u okviru rastegnute komunikacije situacije (Assmann, 2008: 24-25), vanjskog područja komunikacijskog sistema nekog društva gdje se kulturni smisao može izmjestiti, pohraniti i ponovo uključiti, odnosno prenijeti u transgeneracijskom slijedu.

4 „Globitno memorijsko polje,,, kovanica riječi globalizacija i digitalizacija (bit kao osnovna jedinica digitalnih podataka), plodotvorni je koncept koji je razvila teoretičarka Anna Reading prilikom 
pohranjenih momenata nekog zbivanja tako i različitih kognitivnih, emocionalnih i vrijednosnih struktura koje akteri uključeni u borbu oko proizvodnje, cirkulacije i osiguranja memorijskih kapitala projiciraju na ove tragove prošlosti. Medijske reminiscencije, otuda, treba razumjeti kao dinamičke kategorije, uvijek u procesu transformacije. Ovaj paradoks između originalnosti događaja i njegove medijske reprodukcije, čime se jedinstvenost događaja u procesu medijskog svjedočenja ukida, jedno je od ključnih pitanja u studijama medija i kolektivnih memorija.

U prostorima medija uspostavljaju se i sankcioniraju „mjesta sjećanja, suvremenih zajednica, društvenointegrativne vizije prošlosti, koje kulturno-političke elite upotrebljavaju s ciljem oblikovanja kolektivnih identiteta. Zapravo, mediji su u današnjem dobu ,jedan od glavnih faktora u kreiranju znanja o historiji i ljudskom sjećanju,, (Erjavec, 2011: 40, op. aut.). Pojednostavljene, personalizirane i lako shvatljive historije koje mediji stvaraju u cjelini svoje - informativne, zabavne, dokumentarne, obrazovne i dr. - produkcije, pri tome su posebno važne za politiku, „koja ih efikasno (is)korištava za vlastitu instrumentalizaciju, u aktuelne političke svrhe i za mobilizaciju ljudskih masa,, (ibidem). Uprošćeni, dramatizirani i spektakularni prikazi povijesti, također, podjednako su interesantni i profitnoj logici tržišta, suvremenoj industriji zabave, koja obiluje produktima iz kategorije „historijskih žanrova,.. Nije pretjerano reći da najveći broj ljudi danas o povijesti uči posredstvom televizije (Edgarton \& Rollins, 2001), kao i da fikcijski i dokumentaristički televizijski portreti prošlosti značajno preobražavaju način na koji mislimo i doživljavamo različite historijske ličnosti, događaje i epohe. ${ }^{5}$

istraživanja suvremenih kultura sjećanja, obrazovanih posredstvom digitalnih tehnologija u okrilju transnacionalnih procesa. Digitalne tehnologije, smatra Reading, konstituiraju nova polja za oblikovanje kolektivnih memorija, koja su istovremeno i algoritamska, geografska i fizička. Kao polimorfni mediji (Hansen, 2006), digitalne tehnologije premašuju distinkcije producent - konzument, javno - privatno, organsko - anorgansko, karakteristične za jednosmjerni model komuniciranja elektronskog doba, stvarajući uvjete za nastanak novih oblika memorijalnih praksi. $\mathrm{Na}$ tragu Deleuzea, Reading tako piše da su memorijska sklapanja u globitnom polju organizirana oko dvije ose: materijalnih praksi i diskurzivnih formacija producenta i konzumenta (tzv. prosumera), koje se dalje konsolidiraju i/ili preobražavaju kroz drugu osu, procese teritorijalizacije i deteritorijalizacije, gdje se vode bitke nad sklapanjem, mobilizacijom i osiguranjem memorijskih kapitala između pojedinaca, nacionalnih, supranacionalnih institucija i transnacionalnih aktera.

5 Kao dokaz tvrdnji dovoljno je navesti samo neke od aktuelnih popularnih televizijskih dramskih serija poput „Obitelj Borgia,,, „Spartak: krv i pijesak,, ,Sulejman Veličanstveni,,, „Tudori,, ,Rim,,, „Vikinzi,, i dr. Također, programski paketi koje nude kablovski operateri obično sadrže nekoliko dokumentarnih programa povijesne tematike. Selekcija tema i način njihovog izlaganja u biti slijede logiku medijske konstrukcije zbilje. 
Ipak, uloga medija u procesima oblikovanja kolektivnih memorija posebno postaje izražena u uvjetima novomedijske ekologije. Primarno se to odnosi na momente socio-kulturnih trauma, kao što su konflikti, krize i katastrofe, tzv. ,prelomni događaji,, u memorijskim kulturama. Opsesija medija za arhiviranjem traumatičnih događaja, omogućena elektronsko-digitalnim mobilnim tehnologijama, uspon praksi „,medijskog svjedočenja, ${ }^{6}$ u kojima se prožimaju producenti i konzumenti (tzv. prosumeri), profesionalno i tzv. građansko novinarstvo, učinila je medije neizostavnim elementom suvremenih kultura sjećanja. Od Zaljevskog rata, rata u $\mathrm{BiH}$, preko terorističkih napada na New York, London i Madrid, „rata protiv terorizma, u Afganistanu i Iraku, sve do ,arapskog proljeća,, uragana „Katrina,, tzunamija u Indoneziji i Japanu mediji posreduju i arhiviraju slike tragedija u realnom vremenu. Prije, $u$ toku i poslije traumatičnih događaja. Mediji tako postaju stalni pratioci trauma sposobni ne samo da pruže prvu utjecajnu definiciju traumatičnih događaja nego i da konstantno prate, oblikuju i nameću njihova pojavljivanja u javnom diskursu i nakon traumatičnih događaja.

Digitalni mediji, zapravo, radikalno preobražavaju odnose pamćenja i zaboravljanja karakteristične za moderno doba (Gared-Hansen, Hoskins \& Reading, 2009). U svijetu opčinjenom prekomjernom povezanošću umnožavanjem, uređivanjem, povezivanjem, dijeljenjem, komentiranjem, „lajkanjem,,-sjećanje postaje pravilo a zaborav izuzetak (Mayer-Schönberger, 2009). Andrew Hoskins u tom kontekstu piše o „postoskudnom dobu, (Hoskins, 2013), ukazujući na strukturne promjene koje su u suvremeno društvo unijele digitalne multimedijalne baze podataka, sposobne teorijski za neograničene mogućnosti pohranjivanja, obrađivanja i nadzora svih vrsta podataka. Nije iznenađujuće što kritičari novih medija, poput Geert Lovinka, pišu o „društvu upita,, aludirajući na „googlizaciju naših života, čija su okosnica upravo baze podataka (Lovink, 2011). Web 2.0 tehnologije, tzv. društveni mediji, indikativni su primjeri suficitarne produkcije tragova o prošlosti. U ovim kvaziprivatnim i polujavnim prostorima svaki momenat života, čak i najbanalnije epizode, smatraju se poželjnim i skladištenja vrijednim podacima. U takvoj prekomjernosti informacija o prošlosti, zaboravljanje kao poništavanje ili rasterećenje informacija imat će sve veću ulogu u društvu 21. stoljeća (Connerton, 2008: 65).

6 Pod izrazom „,medijsko svjedočenje,, podrazumijeva se ,istovremeno pojavljivanje svjedoka u medijskim izvještajima, mogućnosti samih medija da svjedoče te pozicioniranje medijske publike kao svjedoka prikazanih događaja, konfiguracija koja se zgodno može sažeti kroz tripartitnu distinkciju između svjedočenja $u$ medijima, svjedočenja pomoću medija i svjedočenja kroz medije,, (Frosh \& Pinchevski, 2009: 1). 
U cjelokupnim studijama medija i kolektivnih memorija, informativna djelatnost zasigurno spada među najslabije istražena područja. Tek su novije interdisciplinarne studije posvetile pažnju značaju novinarstva u izgradnji, održavanju i mijenjaju javnih percepcija, osjećaja, vjerovanja i znanja o prošlosti. ${ }^{7}$ U konvencionalnom shvaćanju uočljiva je dvostruka marginalizacija novinarstva: slabo razumijevanje funkcije novinarstva u radu kolektivne memorije s jedne strane, ali i odsustvo svijesti o funkciji prošlosti u radu novinarstva s druge strane (Zelizer, 2008: 80). U radovima ključnih teoretičara kolektivne memorije, tvrdi Zelizer, uloga novinarstva nikada nije sistematično izučavana. Također, isto vrijedi i da važnost novinarstva $u$ posredovanju prošlosti nerijetko nije prepoznata ni kod samih novinara koji „,niti eksplicitno pričaju o prošlosti niti prošlost uzimaju u obzir kao dio svog očiglednog djelokruga, (ibidem). Pomnije ispitivanje, međutim, ne podržava ova uproštena konvencionalna shvaćanja.

Kako ukazuje Carolyn Kitch, novinarstvo je jedno od središnjih mjesta sjećanja suvremenog društva (Kitch, 2008: 311). Velik dio onoga što znamo o prošlosti dolazi iz medija. Naše percepcije o prošlosti u velikoj mjeri su određene novinarskim perspektivama, a novinarski registri o prošlosti važan su izvor informacija o događajima, praksama i temama nekog prošlog vremena pa su u tom smislu neizostavna komponenta memorijskih kultura. Posebno je to izraženo kod novinarske obrade komemorativnih događaja, naročito obljetnica, koje mediji koriste da bi reinterpretirali javne ideale i društveno (ne)poželjne figure sjećanja, ali i predstavili sebe kao neizostavne hroničare društvene zajednice, koji značajno uvjetuju oblike i retoriku komemorativnih rituala. $^{8}$

S druge strane, prošlost je također neizostavni dio same novinarske profesije. Vijesti, naime, zahtijevaju kontekste pomoću kojih se novost tumači i razumijeva. Novinari su upućeni na prošlost i aktivno je koriste u razumijevanju sadašnjosti. Jill Edy je novinarsku upotrebu prošlosti

7 Pogledati, naprimjer, radove Zelizer (1992, 2008), Edy (1999, 2006), Kitch (2002; 2008), Schudson (1992), Nieger, Meyers \& Zandberg (2011), Zandberg (2010), Philips (2004) i dr.

8 U istraživanju obljetničkih novinarskih formi u Sjedinjenim Američkim Državama Kitch piše: „Danas su masovni mediji središnji za američko razumijevanje prošlosti. Obilježavajući jubileje događaja - od Pearl Harbora do Woodstocka do I Love Lucy - filmovi, publicistika i televizijski specijali reinterpretiraju njihovo trajno značenje za državu, koristeći ove priče da razmotre američke ideale i identitet.,, (Kitch, 2002: 44-45). Slične prakse uočljive su i kod bh. medija. Tako je najstariji bh. dnevnik „Oslobođenje,, u specijalnom izdanju povodom 70. obljetnice (br. 23968 od 30. 8 .2013.) reproducirao, prema izboru uredništva, najznačajnije događaje o kojima je izvještavao od 1943. godine. Podsjećajući na događaje koji su obilježili suvremeno doba, mediji na ovaj način nude svojevrsne referentne tačke sjećanja posredstvom kojih zajednica sagledava, prepoznaje i modificira identitetske obrasce kroz vrijeme. 
razvrstala u tri kategorije: komemoracije, historijske analogije i historijske kontekste (Edy, 1999: 71). Komemorativne tekstove novinarske organizacije koriste kako bi publiku podsjetili na važne društvene događaje, ali i (de) legitimizirali različite skupove narativnih repertoara prošlosti koje društveni akteri promoviraju u javnoj sferi. Osim podsjećanja na javno značajne epizode povijesti, novinari nerijetko povlače i paralele između suvremenih i nekadašnjih događaja, odnosno, nastoje situirati aktuelne situacije u šire povijesne kontekste. Historijske analogije i kontekstualizacije tako novinarskim organizacijama nude pozicije autoriteta u upotrebi prošlosti pri objašnjenju sadašnjosti, i obratno. Prošlost i historija, ne treba zaboraviti, omiljene su teme i u popularnoj kulturi. Kitch je uočila kako se istraživanja o odnosu medija i kultura sjećanja većinom fokusiraju na analize izvještavanja „elitnih,, medija o „ekstremnim,, događajima (poput ratova, atentata, prirodnih nepogoda i sl.) u formama tzv. ,tvrdih vijesti,, (hard news) dok se narativno novinarstvo (feature journalism), tzv. „mekše vijesti,, (soft news) obično zapostavljaju. Ove tradicionalno ,ženske strane štampe,,, tzv. tematski okvir „4F, (food, fashion, family, furnishing) isto tako obiluju retrospektivnim sadržajem: člancima o „retro,, modi i dekoracijskim stilovima, velikim momentima u sportskoj i filmskoj historiji, profilima nekadašnjih poznatih osoba (tzv. where-are-they now celebrity profiles), obljetnicama događaja iz historije lokalnih zajednica itd.

Jedan od vjerovatno najvećih izvora nesporazuma $\mathrm{u}$ razumijevanju uloge novinarstva u procesima oblikovanja kolektivnih memorija jeste očigledna, samorazumljiva isključenost $i$ odsustvo prošlosti iz same definicije informativne djelatnosti. Donekle se, zapravo, i čini paradoksalnim povezati „kulture sjećanja,, usmjerene ka obradi sadržaja prošlosti, i „kulturu vijesti,, (Allan, 2004), koja u svom središtu ima novost, socijalne situacije suvremenosti, same aktuelne događaje današnjice. Kako, stoga, prevazići ove proturječnosti? Kako prošlost može ući u prostore medija i postati predmetom novinarske obrade? Odgovor je jednostavan: kao i sve druge medijske teme, samo u obzoru (diskursa) vijesti. Drugim riječima, kao aktuelna prošlost.

Naime, informativna produkcija, odnosno, vijest predstavlja središnji rad u polju novinarstva. Prošlost, prema definiciji ${ }^{9}$, nije predmet žurnalizma nego suvremenost, dakle, dimenzija sadašnjosti/aktualiteta, događaji današnjice (žurnalizam od fr. jour, dan, journal, dnevni). U pravilu, novinari se ne bave

9 „Novinarstvo je djelatnost ili praksa produkcije i diseminacije informacija o suvremenim temama od općeg javnog interesa i važnosti. To je djelatnost skupa institucija koje periodično publiciraju (obično dnevno) informacije i komentare $o$ suvremenim temama, u pravilu predstavljene tačno i istinito, raspršenoj i anonimnoj publici s ciljem javnog uključenja publike u diskurs za koji se drži da je javno značajan.,, (Schudson, 2003: 11). 
poviješću, izuzev ako teme prošlosti nisu (re)aktualizirane kao bitna pitanja suvremenosti, samog razumijevanja današnjice. Prošlost u medijima nastupa uvijek kao aktualna prošlost, pri čemu su sami kriteriji (re)aktualizacije tema prošlosti bitna, ako ne već i ključna, analitička dimenzija. Izrazom ,aktualna prošlost,, želimo ukazati upravo na prožimanje sadašnjosti i prošlosti: istovremeno su to i aktualni događaji, teme relevantne za sadašnje (i buduće) socijalne situacije, i događaji prošlosti, teme strukturno upućene na ranija, prošla zbivanja. Prošlost, stoga, može ući u medije samo u obliku informativno vrijednog događaja, dakle kao vijest. Tretman prošlosti u informativnoj djelatnosti uvjetovan je kriterijem vijesti, te se u skladu s ovim produkcijskim načelima (uz također principe simplifikacije i selektivnosti) medija mora i razumijevati. Polazeći od ovih stajališta u nastavku ćemo nastojati osvijetliti prakse obrade prošlosti u polju novinarstva.

\section{Medijska konstrukcija kolektivnih sjećanja: prakse, operacije i strategije obrade prošlosti u polju novinarstva}

Kao institucija kolektivne memorije, novinarstvo figurira kao složeno polje produkcije značenja (smislotvorstva) prošlosti. S jedne strane, mediji su arena unutar koje različiti (moćni) društveni akteri vode „mnemoničke bitke, s ciljem priznanja određenih diskursa sjećanja u sferi javnosti. Svaki akter, u tom smislu, teži osigurati (samo) jednom skupu narativa, među mnoštvom drugih, konkurentskih prikaza prošlosti, dominantnu poziciju u javnosti, tj. učiniti jednu perspektivu povlaštenom (univerzalnom) tačkom motrišta povijesti. S druge strane, mediji su međutim i sami akteri s autoritativnom pozicijom u ovom polju, elitni članovi interpretativne zajednice društva koji aktivno usmjeravaju javnu upotrebu prošlosti. Uloga novinarstva u procesima oblikovanja kolektivnih memorija određena je ovom dvostrukom pozicijom, temeljem koje mediji istovremeno figuriraju i kao zona u kojoj se nadmeću dominantni prikazi prošlosti ali i kao aktivni „,igrači,, koji svjesno i/ili nesvjesno podržavaju, osporavaju ili ignoriraju „odabrane,, predstave povijesti koje se posreduju u areni (Zandber, 2010; Nieger, Oren \& Zandber, 2011).

Izraz konstrukcija koristimo kao sveobuhvatni pojam za označavanje praksi izgradnje značenja prošlosti, kognitivnog rada u polju novinarstva. Konstrukcija, u osnovi, opisuje simboličke procese/aktivnosti posredstvom kojih novinari oblikuju repertoare naracija prošlosti, a koje uvjetuju sve subjektivne (habitusi) i objektivne (strukture) sile u polju medija. Ključna radnja konstrukcije je strukturiranje značenja prošlosti: izgradnja spirala 
signifikacija ili simboličkih interpretativnih mreža koje (pred)određuju percepciju i okvire znanja prošlosti. Pojam, zapravo, opisuje „strukturirajuće strukture,, sisteme obrazaca opažanja i vrednovanja, svojevrstan kategorijalni aparat posredstvom kojeg se „kodificira, - (ra)spoznaje, imenuje, iskazuje, opisuje, vrednuje, definira, razumijeva - svijet prošlosti. Izrazom primarno želimo ukazati na društvenu uvjetovanost interpretacije prošlosti. Okviri posredstvom kojih se spoznaje, tvori i iskazuje značenje prošlosti, naime, imaju društvenu genezu, odnose koje ih omogućuju, dovode u postojanju i što je posebno važno - konstantno potvrđuju kao takve, legitimne kategorije znanja i imenovanja povijesti.

Prošlost, jedna od tri vremenske dimenzije stvarnosti, fundamentalni je resurs praksi konstrukcije. Kao aktivnost usmjerena definiranju (imenovanju) i predstavljanju (izlaganju) prošlosti posredstvom kompleksa signifikacija, konstrukcija je neodvojiva od komunikacije, simboličkog procesa pomoću kojeg se proizvodi, održava, dorađuje i preobražava (društvena) stvarnost (Carey, 2009: 19). Teorija konstrukcije prošlosti implicira teoriju masmedijske konstrukcije stvarnosti, jer tematizira proces uspostavljanja, održavanja i mijenjanja zajedničkih okvira razumijevanja (viđenja) svijeta prošlosti. ${ }^{10}$ A „kao i bilo koji drugi oskudan resurs, stvarnost je predmet nadmetanja, sukobljavanja različitih ciljeva i projekata; pridaju joj se različita značenja i mogućnosti, troši se i konzervira, racionalizira i distribuira. Temeljni oblik moći je upravo moć da se definira, podijeli i predstavi ovaj resurs.,, (Carey, 2009: 66). Prošlost se, u ovom smislu, može promatrati kao višeznačan simbolički konstrukt, u čijem oblikovanju sudjeluju različiti društveni akteri, a danas sve više mediji kao „vrhovna institucija javne sfere,, (VoćkićAvdagić, 2002). Procesi oblikovanja značenja prošlosti, samo sjećanje kao čin semiotiziranja (smislotvorstva), u biti su komunikacijski procesi u kojima zajednica i njeni vladajući slojevi nastoje povijest prikazati na jedan određen način, u nizu mogućih predstavljanja.

Procesi simboličke obrade tragova povijesti ovaploćuju se u obliku medijskih tekstova: simboličkim konstruktima, rezultatima, iskazima i

10 Izraz teorija ovdje koristimo u izvornom značenju riječi (grč. theorein - vidjeti), kao način viđenja ili perspektivu promatranja svijeta, to jeste, obrasce strukturiranja stvarnosti. Svaka struktura implicira određene principe podjela (poput dualizama muško - žensko, dobro - zlo, visoko - nisko, snažno - slabo, najstarijih načela strukturacija u ljudskom društvu) spram kojih se stvaraju odnosi smisla, i koji organiziraju - istovremeno ograničavajući tim istim okvirima - spoznaju društvene stvarnosti. Nametanje određenog viđenja stvarnosti, stoga, ne shvaćamo u smislu propagandnomanipulacijskih akcija, nego na tragu Baudrillarda i Kafke, kao kolanje određenog kôda, spram kojeg je kodificirana stvarnost, tj. utvrđene podjele - granice - koje omogućuju određene društvene (id)entitete. 
materijalizacijama praksi strukturiranja značenja prošlosti posredstvom diskursa informativne djelatnosti. „Konstrukcija,, i „konstrukt, su u dijalektičkom spoju: kognitivne, društveno uvjetovane strukture spoznavanja i imenovanja povijesti tekstu daruju značenje, to jest, diskurse sjećanja koji sadržaje prošlosti povezuju u smisleni poredak, a zauzvrat ih tekst simbolički izražava u društvenim odnosima, odnosno komunikacijskim činovima. „Konstrukcija,, i „konstrukt,, ne mogu se odrediti u smislu kauzalnih odnosa, budući da određeni regulirani skup iskaza o prošlosti jednom proizveden može biti podloga stabiliziranju društvenih odnosa temeljem kojih nastaje, dakle, njihovoj daljoj reprodukciji, ali isto tako može figurirati kao osnova za nastanak novih strukturacija, dakle, može ih (djelomično ili u potpunosti) preobražavati. Konstrukt, stoga, promišljamo kao simbolički kompleks koji nema zatvorenu nego otvorenu strukturu.

Kao što smo istakli u prethodnom dijelu, informativna produkcija, odnosno, oblikovanje diskursa vijesti predstavlja središnji (kognitivni) rad u polju novinarstva. Ako se oslonimo na „sociologiju vijesti,,, kakvu predlaže Michael Schudson, onda za (diskurse) vijesti možemo kazati da izražavaju javno(sti) značajne teme, ili kako Schudson kaže vijesti su ono što je javno(sti) značajno, odnosno, ono što je javno(sti) istaknuto kao značajno (Schudson, 2003: 6). Uvodeći kvalitetu ,javnog značaja, kao princip distinkcije, pripisujući događajima različite (informativne) vrijednosti, vijesti strukturiraju društvene situacije u odnose nejednakosti omogućujući utvrđivanje razlike u obimu (javno značajan - beznačajan) i vrsti (više-manje javno značajan) medijskog događaja. Nejednaka vrijednosti događaja, omogućena kvalitetom ,javnog značaja,,, u tom smislu temeljna je pretpostavka, uvjet važenja vijesti. Sa ,javno značajnim,, događajima postaju moguće razdiobe na one koji su u poziciji da znaju više (izvori) i manje (publika) o ovim događajima, a time i odnosi posredovanja (novinari), to jest, informiranja. ${ }^{11}$ „Javni značaj,,, međutim, nije neka takoreći „objektivna,, „prirodna,,, „supstancijalna,, kvaliteta događaja. Ova svojstva su predmet „,konvencije,,: postoje samo unutar društvenih okvira koji propisuju i određuju što je i ,javno,, i „značajno,.. Kvalitete ,javnog značaja,,, dakle, rezultat su odlučivanja. Odluke o ,javno važnim,, događajima donose se u polju medija, a njih donose urednici-novinari; uvjetovane su raznim eksternim i internim silama na kojima počiva polje novinarstva. Iako se „objektivno,, ne može ustanoviti zašto je neki događaj važniji od drugog, temeljna pretpostavka

11 Informacija je u biti relacioni - ako ne i relativni - pojam: ovisi od razine saznanja o predmetu informiranja. Apsolutno znanje, spekulativno kazano, isključuje postojanje informacije (jer posjeduje sve informacije). 
u svijetu medija je da postoji nejednaka vrijednost događaja i da njihovo razgraničavanje jeste nadležnost novinarstva. Procesi obrade vijesti u tom smislu mogu se shvatiti kao prakse odlučivanja o nizu operacija posredstvom kojih se strukturira vijest, to jest, definira i obrađuje javno značajan događaj. ${ }^{12}$

Prošlost, stoga, postaje moguća kao medijski sadržaj tek kada su teme povijesti reaktualizirane kao bitna pitanja suvremenih socijalnih situacija, samog razumijevanja današnjice. Kratko kazano, kada se povijesna zbivanja pojavljuju u obliku informativno vrijednih događaja, samih vijesti. Tretman prošlosti u polju novinarstva mora se razumjeti i istraživati u okrilju procesa obrade (diskursa) vijesti o ,javno značajnim,, epizodama povijesti. U slučaju praksi medijskih konstrukcija kolektivnih sjećanja, procesi simboličkih strukturacija prošlosti u polju novinarstva tako podrazumijevaju odlučivanje o najmanje tri ključne operacije u polju javnosti, dominantno u nadležnosti informativne djelatnosti odluke o:

- izboru relevantnih događaja - mjesta sjećanja (ili: definiranje kriterija (re)aktuelizacije tema prošlosti),

- oblicima/sadržajima medijskih diskursa sjećanja (ili: definiranje semiotičkih okvira pomoću kojih će određeni aspekti prošlosti biti definirani, organizirani i izloženi u medijima), te

- preduvjetima za stjecanje autoriteta u oblikovanju naracija o prošlosti.

U osnovi, proces konstrukcije značenja prošlosti u polju novinarstva je proces (de)legitimiranja određenih oblika znanja, razumijevanja i predstavljanja prošlosti usmjerenih javnosti. Riječ je o konstantnom odnosu osporavanja jednih (nelegitimnih) i priznavanja drugih (legitimnih) simboličkih konstrukcija ili interpretacija povijesti posredstvom diskursa vijesti. Kao vrhovna institucija suvremene javne sfere mediji su neizostavno

12 Procesuiranje masmedijske informacije pretpostavlja serije odluka o operacijama selekcije, predstavljanja i autorizacije javno značajnih događaja posredstvom kojih se oblikuje diskurs vijesti. Operacija selekcije obuhvata djelatnosti odabira relevantnih, informativno vrijednih događaja prošlosti. Preduvjet odabira je radnja razgraničenja javno značajnih - beznačajnih događaja, koje se vrši posredstvom kriterija vijesti.

Operacija predstavljanja sastoji se od dvije, međusobno uvjetovane podoperacije: izdvajanja relevantnih aspekta odabranog događaja (informacija per se) i izlaganje ovog sadržaja u obliku masmedijske poruke (informacija per nos).

Uočavanje i izdvajanje relevantnih aspekta, općenito kazano, vrši se posredstvom klasične novinarske formule , $5 W+H$,, dok se izlaganje mentalne predodžbe događaja u verbalno-simboličku strukturu odvija u skladu s novinarskim stilom, žanrom i dodijeljenim prostorom/vremenom.

Operacija autorizacije podrazumijeva verifikaciju prikaza događaja posredstvom odabranih izvora koji potvrđuju validnost konstrukcije stvarnosti pomoću diskursa vijesti. Sve tri operacije u biti su međusobno ovisne radnje i mogu se samo uvjetno, u analitičke svrhe, raščlaniti i odvojeno promatrati. 
polje artikulacije naracija prošlosti i jedno od najefikasnijih institucionalnih arena za širenje i učvršćivanje onih diskursa sjećanja koji u određenoj zajednici žele osigurati hegemonijsku poziciju. Odlučivanje o javnoj egzistenciji određene socijalne situacije, odnosno, proizvodnja posebne kulturne forme vijesti, sankcioniranje onoga što je javno(sti) značajno vrhovna je vrijednost, simbolički kapital imanentan polju novinarstva. Utjecajnost medijskih definicija prošlosti, stoga, ne proizlazi iz kvaliteta njihove eksplikacije povijesnih događaja, koji su uglavnom uprošćene i dekontekstualizirane pripovijesti, nego upravo zbog legitimiziranja određenih praksi spoznavanja i imenovanja prošlosti, koje direktno i/ili indirektno, svjesno i/ili nesvjesno novinari koriste prilikom obrade (re)aktualiziranih događaja prošlosti posredstvom diskursa vijesti. Pre(u)pisati određeni skup naracija, znanja i vjerovanja o prošlosti u svije(s)t javnosti pomoću medijskih tekstova znači učiniti date figure sjećanja priznatim, javno povlaštenim i posvećenim perspektivama sagledavanja prošlosti. Svaki narativ prošlosti teži ovom statusu: osigurati kapital medijski privilegirane, prestižne, utjecajne, dakle, javno značajne vizije prošlosti. Težnja za očuvanjem, odnosno, preobražajem određenih medijski privilegiranih definicija prošlosti u biti je permanentan proces u polju novinarstva, uvjetovan odnosima sila na kojima ono počiva.

Zato prilikom analize nije dovoljno samo promotriti kako se sjećanja oblikuju posredstvom praksi informativne djelatnosti nego i kako se pomoću odluka o operacijama strukturiranja vijesti o prošlosti vrši (strateška) afirmacija ili negacija određenog predstavljanja prošlosti kao legitimnog okvira razumijevanja povijesti. Smatramo da u tom kontekstu može govoriti o najmanje tri medijske strategije operacionalne u tretmanu prošlosti posredstvom novinarskih praksi:

- glorificiranje kristalizira događaje prošlosti u simbole pamćenja,

- osporavanje ističe međusobno suprotstavljene vizije prošlosti i

- ignoriranje ne priznaje događaj prošlosti kao relevantan memorijski resurs.

Utjecaj ovih strategija na proces odlučivanja o operacijama strukturiranja vijesti čini ove odluke strateškim, odlukama u funkciji (de)legitimacije određenog prikaza prošlosti u polju novinarstva. 


\section{Krajolici trauma i medijske reminiscencije: opća obilježja novinarskog tretmana ratne prošlosti u postdejtonskoj BiH}

Polazeći od prethodno elaboriranog modela praksi obrade prošlosti u polju novinarstva, u nastavku prikazujemo opća obilježja tretmana tema ratne povijesti u bh. informativnim medijima. ${ }^{13}$

U pogledu normi selekcije, tri sadržaja ratne prošlosti (1992-95) figuriraju kao ,izvori sjećanja,, u prostoru medija:

- iskustva nasilja i gubitaka, to jest, traumatična sjećanja, sadržaji prošlosti obilježeni iskustvima individualnih i grupnih viktimizacija, poput ubijanja, silovanja, zlostavljanja, progona, oduzimanja i uništavanja imovine i drugih oblika zločina;

- iskustva konflikta, to jest, patriotska sjećanja, epizode ratne povijesti obilježene vojničko-političkim trijumfima i porazima, poput značajnih vojnih operacija, odnosno, diplomatskih kampanja i sličnih političkih akcija tokom ratnog perioda $\mathrm{i}$

- iskustva ratnog profiterstva, to jest, nelagodna sjećanja, koja obuhvaćaju pojedinosti iz „ratne biografije,, pripadnika vladajućih elita, odnosno, prešućenu i zatomljenu ratnu prošlost „eminentnih osoba,, iz političkog, ekonomskog, kulturnog i drugog društvenog miljea.

Najznačajniji sadržaji ratne povijesti u novinarskom tretmanu prošlosti čine traumatična sjećanja ${ }^{14}$, koja se u sadržajima medija pojavljuju posredstvom

$13 \mathrm{U}$ nastavku predstavljene orijentacione karakteristike novinarskog tretmana tema ratne povijesti temelje se na podacima prikupljenim u okviru empirijskih istraživanja tokom rada na doktorskoj disertaciji „Medijska konstrukcija kolektivnih sjećanja u postdejtonskoj $\mathrm{BiH}$,, koju je autor odbranio na Fakultetu političkih nauka u Sarajevu u maju 2013. godine. Analitički korpus obuhvaćao je sadržaje reprezentativnih printanih $(\mathrm{N}=784)$ i elektronskih $(\mathrm{N}=223)$ medija, publicirane $u$ odabranim intervalima tokom 2009. i 2010. godine, koji su analizirani, između ostalih, uz pomoć metoda analize sadržaja i kritičke analize diskursa.

14 Od 1980-ih godina traumatična iskustva viktimizacija, sama negativna sjećanja, potisnula su dijalektiku trijumfa i poraza, dva ključna pola između kojih se odvijaju procesi konstrukcije kolektivnih identiteta u nacionalnim kulturama sjećanja (Assmann, 2011). U okruženju utemeljenom na idealima individualne sreće, trenutnim zadovoljstvima i čuvenosti/slavi, u težište javne svijesti ulaze, tvrdi Bauman, figure žrtve i poznate ličnosti, dok se djela heroja i mučenika, središnjih mnemotopa nacija-država i predmodernih zajednica, čine anahronim, iracionalnim i odbojnim (Bauman, 2009). Transnacionalni procesi potiču otklon od slavne, monumentalne prošlosti i razvijanje senzibilitetima prema povijesnim iskustvima viktimizacije. Naravno, riječ je o intencionalnim odnosima, budući da je transnacionalnim institucijama bitna ne toliko ,povijesna istina, koliko dozirana idejna suglasnost koja neće remetiti procese po(u)vezivanja, bile to politički motivirane integracije ili globalni tok multinacionalnog kapitala (Kuljić, 2006: 191). Nije 
novinarske obrade (izvještavanja, komentiranja i/ili analiziranja) tri vrste medijskih događaja: procesa traženja u ratu nestalih osoba, obilježavanja tragičnih datuma ratne povijesti i krivično-pravnih procesuiranja osoba osumnjičenih za ratne zločine. Ova tri makrotematska kruga predstavljaju okvire pojavljivanja ili aktualizacije traumatične prošlosti u bh. medijima. Iako je za svaki makrotematski krug moguće utvrditi serije posebnih preferencija prilikom selekcije događaja iz prošlosti, u općem smislu sve preferencije povezuje princip vijesti: potraga za neočekivanim, iznimnim, nesvakidašnjim, ekskluzivnim, senzacionalnim, spektakularnim, tajnim, nedovoljno osvijetljenim epizodama ratne povijesti, što je temeljni uvjet pojavljivanja tema prošlosti u prostorima medija.

Ispitivanje simboličkih okvira predstavljanja ratne prošlosti ukazuje na svojevrsnu „kolonizaciju,, i „monopolizaciju,, cijelog (ili značajnog dijela) diskursa o prošlosti od strane diskursa (auto)viktimizacije, što je vjerovatno jedan od značajnih činilaca dominacije traumatičnih epizoda ratne povijesti u medijskim sadržajima o nedavnoj prošlosti. Analiza je, zapravo, pokazala kako postoji jedan zajednički repertoar signifikacija, evidentan i kod međusobno suprotstavljenih prikaza ratne povijesti. Tako se prilikom artikulacije iskaza uočavaju sljedeće diskurzivne konstante: žrtve se, ali i krivci, predstavljaju u skupnim kategorijama, bilo pomoću općih (npr. izmasakrirani civili, ubijeni vojnici, nestale osobe, posmrtni ostaci itd.) ili partikularnih (etničkih) odrednica, obim stradanja se numerički kvantificira, sakralna simbolika ističe prilikom komemorativnih rituala, stravičnost viktimizacije naglašava, dok se povijesna zbivanja predstavljaju uglavnom uprošteno, nerijetko s mitološkim prizvucima. ${ }^{15}$ Zasnivanje i izgradnja spirala signifikacija na ovim narativnim osloncima ukazuje da novinarska obrada događaja prošlosti privilegira dominantne etnonacionalne diskurse, čije je ključno obilježje isticanje razlike u stradanju dva ili više kolektiva, to jest, njihovo međusobno odmjeravanje. Gramatička struktura priče tako se manje-više dosljedno koncentrira na

iznenađujuće stoga što Europska unija svoje utemeljivačke pripovijesti pronalazi u Holokaustu, ali i drugim traumatičnim iskustvima iz ,zajedničke europske povijesti,,, poput partijsko-državnih zločina, genocida, ,etničkih čišćenja,,, ,,dobrovoljnih migracija,,, kolonijalističkih eksploatacija kao i ratnih nesreća, kriza i katastrofa (Leggewie, 2011). Popularnost politika ispričavanja za zlodjela počinjena u prošlosti, ali i sve češći „,viktimizacijski nacionalizmi,, (Lim, 2010), zapravo su lice i naličje uspona kulture negativnih pamćenja. Novije memorijske kulture postdejtonske $\mathrm{BiH} \mathrm{u}$ tom smislu nisu nikakav izuzetak nego tek specifičan, lokalni slučaj, gdje su povijesna iskustva viktimizacije bila upotrijebljena kao gradivni materijali za stvaranje novih-starih etnonacionalnih zajednica (Mahmutović, 2012).

15 Na primjer, određivanje konflikta kao „odbrambeno-otadžbinskog rata,, ili „,domovinskog rata,, s implicitnom mitologijom ognjišta, majke domovine i ratničke, muške otadžbine. 
nekoliko istih pitanja, oko kojih se plete priča o ratnom događaju: koliko je i ko stradao, pri čemu je u žiži određivanja u krajnjoj instanci utvrđivanje etnonacionalne identifikacije žrtava, kakva je narav događaja boli i, što je posebno važno, ko je krivično-pravno odgovarao za zločin?

Dominantni legitimni narativni autoriteti dalje se, donekle, sami logički nameću. Riječ je o biografskim izvorima, žrtvama i udruženjima žrtava, koji imaju ,posljednju riječ,, u pogledu ,deskripcije,, ratnih trauma, i stručnopravnim izvorima, koji donose „,posljednji sud,, u pogledu „eksplikacije, povijesnih događaja, dakle, u spornom predmetu utvrđuju i imenuju „činjenično stanje,, „karakter događaja,, i ,minimalni broj žrtava,.. U dominantnim diskursima, biografski i sudski autoriteti obrazuju ,subjektivne,, i „objektivne,, polove „povijesne istine,,, između kojih se odvija medijska konstrukcija prošlosti. Ostale klase izvora (npr. institucionalni, religijski, akademski i sl.) popunjavaju ,međuprostor,, između ovih krajnosti, podupirući ili osporavajući njihov autoritet u oblikovanju predstava prošlosti.

Dominantni obrasci obrade prošlosti u ,medijskom memorijskom polju,, legitimiziranje etnonacionalnih vizija prošlosti posredstvom diskursa vijesti, polučuju najmanje dva paradoksa: supostojanje međusobno oprečnih diskursa sjećanja i kodificiranja iskustava abjekcije istim onim skupovima signifikacija koji su i inducirali ratne traume. Oslanjajući se na novije kritičke studije o postdejtonskoj BiH, posebno rad bh. politologa Nerzuka Ćurka i kulturologinje Jasmine Husanović, u nastavku ćemo pokušati pojasniti uvjete koji omogućavaju ove proturječnosti.

To što u postdejtonskoj $\mathrm{BiH}$ postoji duboka nesuglasnost o elementarnim dijelovima narativa sjećanja, naravi događaja nasilja (agresija/genocid ili građanski rat/ratni zločin), krivcu (jedna strana ili svi podjednako) i žrtava (jedan ili svi narodi), nije nikakav novi uvid. Prosta usporedba novinarskog izvještavanja o ratnim događajima, poput, recimo, masakra civila na Kapiji u Tuzli ili (ne)obilježavanja Referenduma o nezavisnosti BiH iz 1992. godine, svjedoči o konfliktnosti medijskih figura prošlosti. Komemorativni simbolizam određene epizode ratne povijesti tako se vrednuje pomoću diskursâ afirmacije, negacije, indiferencije/ignoriranja, dominantnih ,osa sjećanja,,, unutar i duž čijih pravaca se suprotstavljene i suparničke naracije uznemirujuće prošlosti međusobno pozicioniraju i suodređuju. Nije teško zaključiti da predstavljanje jednog istog događaja na različite načine - nerijetko sa sasvim oprečnim interpretacijama - rezultira učvršćivanjem i institucionalizacijom međusobno suprotstavljenih prikaza prošlosti u polju javnosti. Odavde obično slijede dva preovladavajuća stajališta. Relativistička pozicija naglašava nemogućnost ili 
teškoću postizanja općeprihvaćenog konsenzusa o ratnoj prošlosti u javnosti, zbog čega se treba „okaniti,, uznemirujuće prošlosti i usmjeriti pogled ka budućnosti. Hegemonijska pozicija, nasuprot njoj, pretpostavlja da su neka razumijevanja ,kontroverzne prošlosti,, ispravnija od drugih, a nakon što se predoče „,nepobitni dokazi,,, potvrđeni pomoću znanosti i sankcionirani putem prava, višesmislenost će iščeznuti, te će u konačnici ostati jedan (jedini) ,pravovjerni,, prikaz povijesti.

Mi, međutim, oba stajališta smatramo problematičnim, zato što zanemaruju i propuštaju ključni uvid, tačku u kojoj se sve tri „ose sjećanja,, ukrštaju i stapaju u jedno: ishodišnu poziciju neodređenosti, zajednički nazivnik cjelokupne javne upotrebe prošlosti u postdejtonskoj BiH. Ono što smatramo ključnim upravo je dispozitiv koji (strateški) projicira, obnavlja i čini mogućim (su)postojanje svih suprotstavljenih vizija povijesti, relativizirajući, zauzvrat, svaku ponaosob. Ili, drugim riječima, osobita temporalna struktura koja, u svojevrsnom modusu aequilibrium indifferentiae, nepremostive razlike u shvaćanjima bh. bliske prošlosti održava u stanju ravnoteže. U nedostatku boljeg termina zovemo je neodređenošću prošlosti, strukturnom koncepcijom vremena u osnovama postdejtonskog poretka koja proizvodi inherentnu manjkavost svake interpretacije povijesti, odnosno, već na razini značenja svaku ,spiralu signifikacije,, pretpostavlja kao problematičan, nepotpun i prije svega neodređen diskurs. Logika u pozadini indeterminacije - logika paradoksa i apsurda - tako u odnosu spram „kontroverzne prošlosti,, osigurava da nijedan akter u ,mnemoničkoj areni,, nije - paradoksalno - ni pobjednik, ali ni gubitnik, što s druge strane znači da iste naracije, simbole i rituale sjećanja svi akteri mogu nastaviti opetovati - in continuo ad absurdum - u polju javnosti.

Mirovni ugovor iz Daytona, naime, konstituirao je $\mathrm{BiH}$ kao sui generis političku zajednicu: inherentno nedovršenu/nesavršenu državu. $\mathrm{Na}$ simboličkoj razini, intencionalnu nedorečenost i manjkavost postdejtonskog projekta državotvorenja možda najbolje izražavaju klasične državničke ikone. Ustav $\mathrm{BiH}$, na primjer, u izvornom obliku napisan je na engleskom jeziku, sačinjen i potpisan izvan $\mathrm{BiH}$, a uz to je i na gotovo misteriozan način ,izgubljen, unutar državnih ustanova. ${ }^{16}$ Himna BiH, nadalje, teško se

16 Originalni bh. (tzv. ,sarajevski,,) primjerak Općeg okvirnog sporazuma za mir, čiji je dio Ustav BiH (Aneks VI), ,izgubljen, , je u institucijama BiH početkom 2008. godine, nakon čega je Ministarstvo vanjskih poslova Francuske, na zahtjev Zastupničkoga doma Parlamenta $\mathrm{BiH}$, dostavilo ovjerenu kopiju Daytonskog sporazuma sa svim aneksima. Ista situacija ponovila se i u Srbiji, jednoj od država potpisnica Sporazuma, koja je također 2008. godine zatražila od Francuske, depozitara Sporazuma, dostavljanje kopije dokumenta, nakon što je utvrđeno da se u državnim institucijama „izgubio,, srbijanski (tzv. „,beogradski,,) primjerak Sporazuma. 
može otpjevati „,patriotski,, budući da muzika nema prateći tekst, čiji sadržaj je višegodišnji politički spor u Parlamentu BiH. Dva entiteta, kao i Distrikt Brčko, od kojih je sastavljena postdejtonska BiH imaju svoje praznike ali ne i država, oko čijeg ,rođendanskog datuma,, u javnosti ne postoji opća suglasnost. Zastava $\mathrm{BiH}$, osim što u ,minimalističkom maniru,, simbolično izražava teritorijalnu cjelovitost i predodžbu $\mathrm{BiH}$, također više govori o projiciranoj „europskoj budućnosti,, na što upućuju zvjezdice i plavo-žute boje, nego što izražava autentična obilježja bh. identiteta itd. Državnonacionalni simbolizam postdejtonske $\mathrm{BiH}$, može se zaključiti, istovremeno - sasvim paradoksalno - afirmira i negira tipične državne ikone (izgubljeni ustav, himna bez teksta, država bez praznika itd.). Postdejtonska $\mathrm{BiH}$ se, zapravo, opire klasičnim kategorijalnim distinkcijama kojima se opisivao univerzum moderne politike (vanjsko/unutrašnje, globalno/lokalno, državanacija/međunarodna zajednica). Rasredištene, ove kvalitete sa Ugovorom iz Daytona stupaju u kompleksne topološke odnose međusobnog preplitanja, uvjetovanja i nerazlučivosti. Nekoliko, sasvim osnovnih, pitanja može to zorno ilustrirati. Šta je, na primjer, osnivački akt, ustav postdejtonske BiH, međunarodni ili nacionalni dokument, proizvod domaćih ili međunarodnih političkih subjekata? Ko je politički subjekt $\mathrm{BiH}$, lokalne (etnonacionalne) političke elite ili predstavnici međunarodne zajednice u BiH? Ko je suveren $\mathrm{BiH}$, bh. građani ili konstitutivni narodi ili vanjski upravitelj? Šta je temeljni politički nacrt bh. stranačkih ideologija, jačanje, izgradnja i integracija ili pak slabljenje, razgradnja i dezintegracija $\mathrm{BiH}$ ? Neodređenost osnovnih atribucija, odnosno prožimanje, uvjetovanje i nerazlučivost prividno oprečnih činitelja, zajednički je nazivnik, lako je uvidjeti, svih pitanja o postdejtonskoj BiH. Otuda su, načelno, pogrešne sve analize koje paradoksna obilježja postdejtonske $\mathrm{BiH}$ iščitavaju kao dokaz bezuspješnosti, nefunkcionalnosti i nemogućnosti $\mathrm{BiH}$ kao države. Isto naravno važi i za njihove obrnute odraze u ogledalu, političke projekte koji djeluju s uvjerenjem da se $\mathrm{BiH}$ kao država može ostvariti kroz dejtonski ustavni okvir. Suprotno ovim pristupima, mi smatramo da kritičko mišljenje počinje onog trenutka kada se ocrtane proturječnosti promisle ne (samo) kao iskazi problematične političke konfiguracije nego kao sam modus vivendi postdejtonske $\mathrm{BiH}$. Načela indistinkcije $\mathrm{i} / \mathrm{ili}$ indeterminacije, imanentne strukturama izuzetka i odnosima simulacije, relevantna su logičko-metodološka načela razumijevanja, primjerena osvjetljavanju složenih političkih konstelacija poput same postdejtonske $\mathrm{BiH}$. Ona su komplementarna, mišljenja smo, novijim interdisciplinarnim pristupima bh. znanstvenika koji postdejtonsku 
$\mathrm{BiH}$ promatraju kao par excellence prostor ispoljavanja suverenih (bio) političkih režima moći i oblika života koje oni produciraju, a koje teoretičari opisuju figurama „golog života,, (Agamben), „ljudskog otpada,, (Bauman) ,multikulturalizma, (Žižek) i sličnim konceptima. ${ }^{17}$

Nerzuk Ćurak tako na više mjesta piše o postdejtonskoj BiH kao „oglednoj zemlji,, (Ćurak, 2002), „državi eksperimentu,, (Ćurak, 2006), testnoj zoni za isprobavanje različitih političkih scenarija, postmodernoj političkoj zajednici koja svoju geopolitičku relevanciju stiče sasvim apsurdno kao ,geopolitička kloaka,", ,poligon za istresanje različitog geopolitičkog trasha, (Ćurak, 2009)..$^{18}$ Slično tvrdi i Jasmina Husanović kada postdejtonsku BiH sagledava kao eksperimentalno polje novih biopolitičkih oblika upravljanja životom i smrću u postkonfliktnim zajednicama. „Bio-kratski,, (inter)nacionalni režimi suverene moći, nisu odgovorni niti jednoj političkoj zajednici nego ,,interesima globalnih i lokalnih, privatnih i državnih elita koje multipliciraju i usavršavaju mehanizme ovladavanja tijelima određene populacije kao proizvodnim sredstvom koje ima nusproizvod, one oblike življenja koji postaju otpad,, (Husanović, 2012: 13).

Budući da između svakog političkog poretka i vremena postoji stanovit odnos (Edkins, 2003), i postdejtonska BiH također pretpostavlja određenu koncepciju temporalnosti, koja podupire njenu političku egzistenciju $\mathrm{u}$ aktuelnom obliku. Koncepcija vremena u osnovi političkog poretka postdejtonske $\mathrm{BiH}$ privilegira dimenzije sadašnjosti i budućnosti, dok prošlost uopće ne pretpostavlja niti kao nužan niti poželjan činilac uspješnog funkcioniranja dejtonske države. Općeprihvatljiv narativ o (zajedničkoj) prošlosti u postdejtonskoj $\mathrm{BiH}$ nije moguće postići, ne zato što sadržaji

17 Vidimo ih u ratu protiv $\mathrm{BiH}$ gdje je razlika između policijskih i kriminalnih struktura, zločinaca i patriota, komšija i neprijatelja, novinara i propagandista, ljudskog i životinjskog, biologije i politike zamagljena i nerazlučiva. Ali, i u postdejtonskoj BiH koja se konstituira u svojevrsnom izvanrednom stanju, u kojem se nacionalne i internacionalne, legalne i ilegalne, legitimne i nelegitimne političke strukture prožimaju i međusobno uvjetuju. Prepoznajemo ih u masovnim grobnicama, ,metaforama za ljudski otpad,,, ali i u životima agregiranim na ,getoizirane prostore,, kakva je sadašnja BiH, kao strategiji uklanjanja i vezivanja za tlo ljudskog otpada, radne snage koja je postala neupotrebljiva i beskorisna iz ugla kapitala/moći (Husanović, 2012: 12-13).

18 U duhu Baudrillarda, Ćurak sasvim tačno uočava simulacijska obilježja političkih odnosa koje pretpostavlja postdejtonska paradigma $\mathrm{BiH}$, koje opisuje atributima kao što su samoreferencijalnost, odsustvo državotvornog sadržaja, oslobođenost svrhe povijesti, prekomjerna proizvodnja prezenta, ispražnjenost bh. (meta)fizičkog prostora bilo kakvim oblicima zajedničkog smisla itd. Tako i piše da je u „ravni zbilje BiH simulacija,, a „u ravni simulacije BiH je zbilja,, (Ćurak, 2005: 9), budući da ovakva tvorevina ima smisla samo u logici simulakruma, gdje se djelo začinje na osnovu svoje reproduktivnosti, indiferentno spram porijekla i svrhe. Kod simulacijskih odnosa, kako je tvrdio Baudrillard, ključna je reproduktivnost samog modela-kôda, koja ne mora biti racionalna (niti ontološka) nego samo operacionalna. 
takve prošlosti ne postoje nego zato što poretku takvo nešto nije potrebno za ustaljeno funkcioniranje. Samo u uvjetima neodređene, to jest, relativizirane i dekonstruirane prošlosti ona može postojati i održavati se u svom sadašnjem obliku, ravnoteži nepremostivih razlika. Otuda se postdejtonska $\mathrm{BiH}$ kao država konstituira uz pretpostavku strukturne indeterminacije prošlosti, što je neophodni uvjet paradoksalnog supostojanja suprotstavljenih prikaza prošlosti u polju novinarstva.

Uz produkciju i institucionalizaciju oprečnih tumačenja ratne povijesti u području javnosti, drugi zajednički imenitelj dominantnih novinarskih diskursa sjećanja su gotovo identične kognitivne matrice i operacije posredstvom kojih se odvija imaginacija uznemirujuće prošlosti. Riječ je o paradoksnom kodificiranju traumatičnog iskustva skupovima signifikacija koji su inducirali upravo ta ista iskustva. Temeljna struktura ovih simboličkih praksi je proizvodnja afektivnih etničkih razlika: svođenje punine ljudskog bića na (isključivo) jedno svojstvo, to jest, reduciranje svih (stvarnih i potencijalnih) dimenzija čovjekovog identiteta na samo jednu veličinu: etničku pripadnost. Ključno „dostignuće, rata upravo je strukturiranje (osmišljavanje) društvene zbilje, odnosno, imenovanje i izlaganje svijeta prošlosti posredstvom etnonacionalnih kategorija. Onih istih politika nominalizacija koje su inducirale traume ratnog nasilja, odnosno, režima predstavljanja koja su sve dimenzije čovjekovog (političkog) identiteta svela na samo jednu dimenziju - nedokučivu, apsolutnu partikularnost, krvno-kulturnu srodnost, sam goli život. Kako razumjeti ove proturječnosti?

U pronalaženju odgovora na ovo pitanje mogu nam pomoći ranije navedeni uvidi o autoritetima posredstvom čijih se iskaza oblikuju prikazi prošlosti u medijskim tekstovima. Klasa biografskih izvora, kao što smo rekli, neumitan je narativni autoritet $\mathrm{u}$ opisu ratnih trauma. Nasuprot njima, klasa stručno-pravnih izvora neosporan je autoritet za objašnjenje događaja nasilja. Ako je prvim svojstvena afektivnost i subjektivnost, onda se za druge vezuje objektivnost. U medijskim tekstovima, posebno izvještajima koji žanrovski teže „objektivnom,, prikazu događaja, tako je evidentna, višemanje eksplicitna, putanja od subjektivnog, afektivnog opisa traumatičnog iskustva, koje iznose žrtve, do hladne, racionalne, objektivne sudske odluke, koja na temelju znanstveno utvrđenih činjeničnih dokaza, „van svake sumnje,, treba da razjasni prirodu zbivanja, žrtve i počinioca, a time na određeni način „deaktivira,,, ,ukroti,,, ,umiri,, i „ohladi,, afektivnost. Obrazac toka vidljiv je u gramatici komemorativnih priča, koje počinju sa stravičnim opisima uznemirujuće prošlosti a završavaju s konstatacijama o sudskim procesima, 
prošlim, trenutnim i budućim, koji su utvrdili, utvrđuju ili nisu još utvrdili činjenice o zlodjelu. Važno je razumjeti konstitutivnu ideološku fantaziju koja se skriva iza ovih trajektorija: vjerovanje u izvanjski stručni autoritet, koji će pomoću znanosti utvrditi, a kroz pravo sankcionirati objektivnu istinu o prošlosti, a time i prevazići primordijalne i tribalne afekte, odnosno, dovesti do procesa pomirenja.

Naime, okosnicu tehnologija kulturaliziranog upravljanja traumom, kako je uočila Jasmina Husanović, čini upravo menadžment afektom, dominantni diskurs (inter)nacionalnih režima moći/znanja/vladanja, koji operira unutar zablude ili vjere u magični legalizam te naučno i birokratsko upravljanje projektom pod zajedničkim nazivnikom izgradnje mira i društvenog pomirenja, praznih označitelja tranzicijske pravde (Husanović, 2010). Terapeutski pristup koji podrazumijeva menadžment afektom u biti predstavlja postpolitičko razumijevanje upravljanja traumom. Naime, ono traumatično iskustvo odvaja od političke sfere i izmješta u polje znanosti, gdje se abjektna tijela suverenih politika, poput krvi, kosti i DNK uzoraka nestalih osoba, matematiziraju i svode na bar kodove $\mathrm{u}$ administrativnom hipertehnologiziranom okruženju koje opslužuje bioinformatiku, forenziku, genomiku i slične znanstvene discipline. Kao što naglašava Husanović, upitna pretpostavka na kojoj se temelji cjelokupna paradigma „terapeutske pravde,, je uvjerenje da se traumom na ličnom i kolektivnom planu može ovladati. Ovakav pristup stoga ne vodi emancipativnim praksama niti kritičkim kulturama sjećanja nego normalizaciji, mitologizaciji i iščezavanju traumatičnog iskustva iz područja javnosti i/ili prepuštanju polju religije (ibidem). Drugo, ono predstavlja pogrešno tumačenje situacije jer je ,stvaranje afektivnih veza i podela obično cilj ratnih zločina, a ne uzrok,, (Wastell prema Husanović, 2012: 15). Ono, zapravo, isključuje odgovornost zajednice, one „koji su zažmurili, koji nisu intervenisali, oni koji nisu znali da nađu Jugoslaviju na mapi, ili ih nije bilo briga za to, , (ibidem). ${ }^{19} \mathrm{I}$, možda najvažnije, terapeutsko upravljanje traumom ,perpetuira iste politike terora i rasističke identifikacije zasnovane na krvi

19 Koncept kolektivne odgovornosti u postjugoslavenskom kontekstu s pozicija liberalizma najdosljednije je razradio Nenad Dimitirijević. Kolektivna odgovornost spram masovnog zločina treba se sagledati, smatra Dimitrijević, u odnosu na prirodu režima koji čini masovna zlodjela i prirodu odnosa između režima i njegovih podanika. Prema njemu „masovni zločin analitički je obeležen sledećim svojstvima: ideološkim opravdanjem, pogotovo načinom na koji ideologija određuje i izdvaja metu mržnje; brojem žrtava; ulogom režima u zločinačkim aktivnostima; brojem počinilaca i saradnika; uverenjima, stavovima i ponašanjem 'običnih ljudi' (Dimitrijević, 2011: 46). Unutar masovnog zločina dalje se mogu razlikovati, prema Dimitrijeviću, dvije podvrste: režimski i kolektivni zločini. Potonje oblike kolektivnog zločina, čija su glavna obilježja ,populistička integracija, koja uključuje visok stepen ideološke i praktične saglasnosti oko zločina,, (ibidem, 54), Dimitrijević prepoznaje u uznemirujućoj prošlosti nedavne ratne povijesti. 
i kosti etnonacionalnog srodstva (...) Vidimo to čak i u radu Međunarodne komisije za nestale osobe čiji je proizvod to da su nestale osobe identifikacijom ponovo reinsertovane $u$ poretke države, etnonacije i religije $u$ ime pravde $i$ budućnosti koju nudi režim terapeutskog vladanja kroz tranzicijsku pravdu, (Husanović, 2012: 14). Menadžment afektom, kratko kazano, mjesto je na kojem se susreću etnonacionalne i neoliberalne kulture trauma i identitarne politike u postdejtonskoj $\mathrm{BiH}$.

Doprinos medija unapređenju kritičkog pristupa razumijevanja tema ratne povijesti ovisi prvenstveno od kapaciteta bh. novinarstva da problematizira ove dominante okvire spoznavanja i imenovanja svijeta prošlosti koje pretpostavlja postdejtonski poredak. Takve prakse nisu oprečne nego naprotiv sukladne temeljnoj aktivnosti-svrsi novinarske profesije: zadatku artikuliranja javnog interesa, koji se ne može omeđiti partikularnim, etnonacionalnim i/ ili neoliberalnim, kulturno-srodničkim i/ili spektakularno-konzumerističkim identitetima. Najmanje dva uvjeta nužna su za postojanje i održavanje tako usmjerene djelatnosti: strukturiranje polja novinarstva na načelima autonomnosti, a novinarskih habitusa na etičkim načelima žurnalističke profesije. Ispunjavanje ovih uvjeta nije samo odgovornost medijskih organizacija nego i cjelokupne zajednice, čije preferencije u pogledu korištenja medija uvijek značajno utječu na preovladavajuće novinarske sadržaje, prakse i institucije.

\section{Zahvale}

Autor se iskreno zahvaljuje profesorici dr. sc. Jelenki Voćkić-Avdagić i profesorici dr. sc. Vedadi Baraković na konstruktivnim komentarima, sugestijama i savjetima, koji su skupno doprinijeli boljem razumijevanju, promišljanju i istraživanju tretmana prošlosti u informativnoj djelatnosti. 


\section{MEDIA-CONSTRUCTED COLLECTIVE MEMORIES: HISTORY TREATMENT IN JOURNALISM WITH FOCUS ON POST-DAYTON BOSNIA AND HERZEGOVINA}

\section{- Abstract -}

In this work we critically consider the practice of treating history in the area of journalism respectively media as an distinctive institutional arena of contemporary communities for establishment, maintenance and transformation of common frameworks of understanding and commemorating of certain episodes from the past. We intent to offer plausible explanations regarding the relations between ,culture of remembrances” and „culture of reporting". Article suggests how to approach the often misunderstood history in informative activity, which in its field of action and by definition does not have the dimension of history but the dimension of social situation of contemporariness. We also form the key operations and strategies used in shaping the repertoire of journalistic reports on the past. Described practices we study on the example of post-Dayton BiH, analysing media treatment of conflict areas during the recent war history. Legitimisation of ethnicnational visions of the past through the discourse of reporting has been recognised as the dominant way of working in the "media memory field". Two key paradoxes of these practices are highlighted: coexistence of opposite discourses of commemoration and codification of abjection experiences by the same group of significations which have initially inducted the war traumas. We point out at least two conditions which facilitate these paradoxes: ambiguity of the past, conception of time which is assumed by post-Dayton Bosnia and Herzegovina as an inherently uncompleted/imperfect country and technologies of culturised steering of trauma, which is being used by regimes of , therapeutic/transitional justice” to cope with disturbing history in postconflict communities.

Keywords: field of journalism, discourse of reporting, culture of remembrance, traumatic memories, post-Dayton $\mathrm{BiH}$. 


\section{Literatura}

- Allan, S. (2004): News Culture, Buckingham: Open University Press.

- Assmann, A. (2011): Duga senka prošlosti: kultura sećanja i politika povesti, Beograd: XX vek.

- Assmann, J. (2008): Kulturno pamćenje (pismo, sjećanje i politički identitet $u$ ranim visokim kulturama), Zenica-Tuzla: Vrijeme \& Nam.

- Bauman, Z. (2009): Fluidni život, Novi Sad: Mediterran Publishing.

- Carey, J. W. (2009): Communication as Culture: Essays on Media and Society, New York: Routledge.

- Connerton, P. (1989): How Societies Remember, Cambridge-New York: Cambridge University Press.

- Connerton, P. (2008): 'Seven Types of Forgetting', Memory studies, vol. 1, no.1.

- Ćurak, N. (2002): Geopolitika kao sudbina (postmodernistički ogled o perifernoj zemlji), Sarajevo: FPN.

- Ćurak, N. (2005): „Kontroverze i paradoksi kvazidemokratskog okvira,,, Zeničke Sveske, 9-12.

- Ćurak, N. (2006): Obnova bosanskih utopija (politička filozofija, politologija $i$ sociologija postdejtonske BiH), Sarajevo-Zagreb: Synopsis.

- Ćurak, N. (2009): „Je li Bosna i Hercegovina važna zemlja? Geopolitičke dileme i imperativ državnosti,,, online magazin Puls Demokratije, dostupno na http://arhiva.pulsdemokratije.net/index. php?id $=1404 \& \mathrm{l}=$ bs.

- Dimitrijević, N. (2001): Dužnost da se odgovori. Masovni zločin, poricanje i kolektivna odgovornost, Beograd: Fabrika knjiga.

- Dudai, Y. (2002): Memory From A to Z. Keywords, Concepts, and Beyond, Oxford-

- -New York: Oxford University Press.

- Edgerton, G. R. i Rollins, P. C. /eds./ (2001): Television Histories: Shaping Collective Memory in the Media Age, Lexington: The University Press of Kentucky.

- Edkins, J. (2003): Trauma and the Memory of Politics, Cambridge: Cambridge University Press.

- Edy, J. (1999): „Journalistic Uses of Collective Memory,„, Journal of Communication, vol. 49, no. 2.

- Edy, J. A. (2006): Troubled Past: News and the Collective Memory of Social Unrest, Philadelphia: Template University Press. 
- Erjavec, K. (2011): „Slučaj Dobrovljačka: analiza srpske i bosanskohercegovačke štampe,,, u Džihana, A. et al. /ured./: Mediji i nacionalne ideologije: analiza izvještavanja o suđenjima za ratne zločine, Mediacentar Sarajevo.

- Frosh, P, \& Pinchevski, A. /eds./ (2009): Media Witnessing: Testimony in the Age of Mass Communication, Houndmills: Palgrave Macmillan.

- Garde-Hansen, J., Hoskins, A. \& Reading, A. (2009): Save As... Digital Memories, Basingstoke-New York: Palgrave Macmillan.

- Hansen, M. (2004): New Philospohy for New Media, Cambridge, MA-London: MIT Press.

- Hoskins, A. (2008): „Collective Memory and Media,, u Donsbach, W. (eds.) The International Encyclopedia of Communication, Malden-Oxford-Carlton: Blackwell Publishing.

- Hoskins, A. (2013): „The End of Decay Time,,, Memory Studies, 6(4).

- Husanović, J. (2009): Između traume, imaginacije i nade. Kritički ogledi o kulturnoj produkciji i emancipativnoj politici, Beograd: Fabrika knjiga.

- Husanović, J. (2010): „Ka emancipativnoj politici svjedočenja: politika nestalih kao vladanje traumom kroz kodifikaciju/ matematizaciju/depolitizaciju na razmeđima (inter)nacionalnih režima 'terapeutske/tranzicione pravde',", transkript javnog predavanja u sklopu Oktobarskog salona u Beogradu 2008. godine, novine Matemi reasocijacije, Grupa Spomenik: Beograd.

- Husanović, J. (2012): „Kultura traume i identitarna politika u BiH: kritika ideologije pomirenja,,, Diskursi - društvo, religija, kultura, godina II, broj 3.

- Kitch, C. (2002): „Anniversary Journalism, Collective Memory, and the Cultural Authority to Tell the Story of American Past,,, Journal of Popular Culture, 36 (1).

- Kitch, C. (2002): Pages from the Past: History \& Memory in American Magazines, Chapel Hill: The University of North Carolina Press.

- Kitch, C. (2008): „Placing Journalism Inside Memory and Memory Studies,, Memory Studies, (1).

- Kuljić, T. (2006): Kultura sećanja: teorijska objašnjenja upotrebe prošlosti, Beograd: Čigoja štampa. 
- Leggewie, C. (2011): „Seven Circles of European Memory,", u Meusburger, P., Heffernan, M. \& Wunder, E. /eds./: Cultural Memories: The Geographical Point of View, Heidelberg-LondonNew York: Springer.

- Lim, J. (2010): „Victimhood Nationalism in Contested Memories: National Mourning and Global Accountability,,, u Assmann, A. \& Conard, S. /ed./ (2010): Memory in the Global Age (Discourse, Practices and Trajectories), Basingstoke-New York: Palgrave Macmillian.

- Lovink, G. (2011): Networks Without a Cause. A Critique of Social Media, Polity Press: Cambridge-Malden.

- Mahmutović, M. (2012): „Novosti o prošlosti: joker za (ne)sigurnu budućnost - prilozi za izučavanje predstavljanja ratne prošlosti u bh. dnevnim novinama,,, Medijski dijalozi - časopis za istraživanje medija i društva, godina V, broj 13-14.

- Mayer-Schönberger, V. (2009): Delete: The Virtue of Forgetting in the Digital Age, Princeton-Oxford: Princeton University Press.

- Misztal, B.A. (2003): Theories of Social Remembering, Philadelphia: Open University Press.

- Neiger, M., Meyers, O.\& Zandberg, E. (2011): On Media Memory: Collective Memory in a New Media Age, Basingstoke-New York: Palgrave Macmillian.

- Nora, P. (2007): „Između sjećanja i povijesti,,, Diskrepancija, svezak 8 , broj 12.

- Olick, J. K., Vinitzky-Seroussi, V. \& Levy, D. (eds.) (2008): The Collective Memory Reader, Oxford: Oxford University Press.

- Phillips, K. R. (ed.) (2004): Framing Public Memory, Tuscaloosa: University of Alabama Press.

- Reading, A. (2011): „Memory and Digital Media: Six Dynamics of the Globital Memory Field,,, u Neiger, M., Meyers, O. \& Zandberg, E. (eds.) On Media Memory: Collective Memory in a New Media Age, Basingstoke-New York: Palgrave Macmillian.

- Schudson, M. (1992): Watergate in American Memory: How We Remember, Foreget and Reconstruct the Past, New York: Basic Books.

- Schudson, M. (2003): The Sociology of News, New York-London: Norton \& Company.

- Voćkić-Avdagić, J. (2002): Suvremene komunikacija (ne/sigurna igra svijeta), Sarajevo: FPN. 
- Wertsch, J. (2004): Voices of Collective Remembering, CambridgeNew York: Cambridge University Press.

- Zandberg, E. (2010): „The Right To Tell The (Right) Story: Journalism, Authority and Memory,,, Media Culture Society, 32 (1).

- Zelizer, B. (1992): 'Covering the Body': The Kennedy Assassination, the Media and the Shaping of Collective Memory, Chicago: University of Chicago Press.

- Zelizer, B. (2008): „Why memory’s work on journalism does not reflect journalism's work on memory,, Memory Studies, Vol 1(1).

- Zelizer, B. (2011): „Canibalizing Memory in the Global Flow of News,,, u Neiger, Motti, Meyers, Oren \& Zandberg, Eyal /eds./: On Media Memory: Collective Memory in a New Media Age, Basingstoke-New York: Palgrave Macmillian. 